\title{
Friendship and the new politics: beyond community
}

\author{
Astrid H.M. Nordin (Lancaster University) \\ Graham M. Smith (University of Leeds)
}

\begin{abstract}
What role can friendship play in contemporary politics? This article answers this question by showing how friendship supplements one of the central tropes of modern European thought: community. It argues that both the recent phenomenon of populism and more traditional political practice rely on this trope. This results in a politics which focuses on identity and difference, inclusion and exclusion. Ultimately this form of politics seeks an immanence which is impossible to achieve. In contrast, friendship offers a new way of thinking about politics as it focuses on open-ended relations between persons based not on sameness, but otherness and difference. The article articulates five key features of this understanding of friendship: (1) that it is a relationship; (2) between self and other; (3) which exists between the friends; which is (4) extendable into a network but not a unity; and (5) it eschews all programmes or projects. In this way, friendship suggests not a project or a programme, but an ethos. This article concludes by claiming that friendship is the open-ended and ongoing encounter with the other, and its politics holds a shared space open for the potential that this encounter brings.
\end{abstract}

\section{Introduction}

What role can friendship play in contemporary politics? This article argues that whilst community has been a central trope of modernity, it is an idea and practice that is both limited and in need of a supplement. That supplement is friendship. To get an inroad into this line of thought this article takes recent attention to the phenomenon of populism as its starting-point. It argues that populism is the most recent convulsion of a wider concern in European political thought and practice: the desire for community. This trope has become increasingly problematic in recent times. Difficulties centre around the tendency of community to focus on sameness at the expense of difference, and for the establishment of community to become a task or programme for politics. Under the trope of community, politics is seen to be about (re)creating a harmonious whole built around identity, and is hostile to difference.

In response to this predicament, it is the claim of this article that friendship can play an important role not only in the analysis of contemporary problems but also in their solution. This contribution of this article is to propose an original understanding of friendship which suggests a new politics. This understanding of friendship responds to contemporary problems in three ways. First, friendship refocuses attention on what has tended to be lost in modern political thought: relations. Friendship suggests that rather than attempt to achieve or understand set and fixed units and identities, we should approach our analysis by looking at fluidity and change. Friendship suggests the co-constitution of political entities. Second, friendship relies not on a politics of identity, but a politics which brings together both identity and difference. In other words, friendship implies both sameness and difference, rather than the self dominating, neutralising, or excluding the other. Third, friendship moves away from the idea of a bounded and unified political subject (community), and an understanding of politics as either populated by, or tasked with creating and maintaining, such entities. Rather than focus on such entities, friendship views politics as a mobile network of relations. In such a vision, people are connected in multiple and 
diverse ways, and these ways cannot be predicted or legislated for beforehand. It is argued here, then, that friendship can offer a new form of politics which moves beyond established ways of thinking that are linked to community as a unified political subject, and prone to outbursts of exclusion, hostility and fanaticism.

The approach adopted here is theoretical and somewhat speculative. As such it offers no direct programme or policy. It is not an attempt to intervene or offer advice to policy-makers or political actors. Nor, it should be noted, is this article simply advocating that political actors be more caring of others or reasonable to each other (however desirable this might seem). Nevertheless, this article is a manifesto of sorts as it is a provocation to thinking differently about the current political scene. It seeks to enable a different kind of analysis and thus a different kind of politics to arise. It offers an account of friendship that is suited to the conditions of the new politics. Indeed, it offers an account of friendship which can transform the contemporary political scene. This is not to say that such transformation will simply happen. However illuminating and laudatory the theory, it is born to a world with which it is currently out of kilter. Theory alone cannot transform the world - but it can provide the possibility of doing so. By rethinking the world theory can create new perspectives and in so doing offer new opportunities for thought and action. Political theory thus transforms the world by transforming the way that we think about the world, and the way that we think about the world conditions the possible and impossible in politics.

The rest of this article proceeds in the following fashion. First, recognising that the connection between friendship and politics will be unfamiliar to many readers, a brief rehearsal of this relationship is staged. Importantly, this rehearsal outlines how friendship is not to be understood in this present discussion: as a private and personal relationship based on the emotions. Although the use of friendship here relates to this view, it also contrasts to it. In this article the analytical importance of friendship is outlined as a site where self and other, sameness and difference, can be negotiated in a shared world of order and value. What is intended by friendship is thus a concern with relations and relationality. In particular, it is a concern with what binds person to person, and group to group. This approach allows us to see that friendship can take many forms, even many political forms - and friendship has many political manifestations.

After this foundational rehearsal of the significance of friendship, section two of this article moves on to think about community through observations about a recent trend in Western politics: the rise of populism. Populism is understood to be a phenomenon that transcends traditional political categories of left and right. Nevertheless, populism has continuities with existing forms of politics. Those subscribing to populism are seeking not just political redress, but group identity. Populism operates on the logic and practice of a worthy or righteous in-group who share a sense of belonging and togetherness. This group is sharply differentiated from those outside who appear as threats and the source of discord and injustice. Thus it is argued that what populism represents is not something entirely new, but the latest convulsion in the search for community.

This leads to the third section where the idea of community is examined in more detail. The desire for community has been one of the central themes of modern European political thought and has translated into political action. It is important to note that in this article we primarily discuss community as a common conceptual or analytical construct. The purpose is to identify and accentuate key features of community, and to highlight how this trope works. It is recognised that actual existing communities might operate by mixing this understanding of community with other ideas and practices. Nevertheless, taken as an analytical concept a community is understood to be based around a common identity and its realisation to be the task of politics. In other words, various political programmes and projects (both explicitly and implicitly) have sought to realise the idea of community: a unified whole based around common characteristics or features. Although no detailed analysis is offered here, this concern can be traced through such thinkers as 
Hobbes, Rousseau, Herder, and Schmitt, all of whom were concerned with the foundations and maintenance of 'sovereignty' and 'the people' in some sense or other. The limitations and problems of community are highlighted by considering three features of community. First, as fantasy community is not something that is realised in the present. It is always something that belongs to the past and is in need of restoration, or it is something that is promised in the future. Second, community proposes to unite a group of people under a common characteristic or attribute. As such it works on a logic of inclusion and exclusion which often manifests in a hostile relation of Us and Them. Finally, community becomes the aim and telos of politics. Such an approach eschews dynamic relations between persons in a shared world for an ossified and totalising mission to achieve immanence between person and person.

In the final part of the article a prima facie case is made for the significance of friendship in addressing these concerns. The idea that friendship can be considered political has already been made in the first part. This final part builds on this work offering a specific and original account of friendship - an account which has normative political implications (although it does not suggest a policy or programme of its own). This account views friendship as having five important features. First, friendship is not a state or an achievement but a relationship. That is to say, it is not a thing but a dynamic. Second, friendship is a relationship between self and other, it is a relationship which involves sameness and difference. Third, as a relationship involving sameness and difference, self and other, friendship indicates an identity which is shared between persons. Friendship is not something that characterises either person as an individual, nor can any individual person possess friendship. Instead, it is a form of shared identity and a shared self. Fourth, although the basic form of friendship might be said to be a dyad, these dyads are not exclusionary of further or even multiple connections. In fact, rather than a closed circle, friendship suggests a criss-crossing of multiple connections into a mobile network of relations. Fifth, friendship offers no programme or project. Its strength is not in what it seeks to realise, but in that it simultaneously holds persons together who share a world, but that there is no direction or terminus to their relationship. It is an on-going way of existing. Friendship is thus capable of variation without exclusion, and is anarchic and anti-authoritarian. Such a vision is a very long way away from the vision of community offered by much modern political theory and promoted by contemporary political programmes. Such a vision points not only to the underlying structure of existing politics, but also to the possibilities of a new politics.

\section{Friendship and politics: a thumbnail sketch}

In recent decades, considerable work has been undertaken reintroducing the idea of friendship to political analysis and the political lexicon (for surveys see Devere and King 2000, Devere and Smith 2010, Devere 2013). This work has focused not only on the contemporary political scene, it has also drawn from a longer and wider tradition within the West and beyond. This work has been undertaken on a number of levels showing that friendship can play an analytical, descriptive, and normative role in the study of politics (Devere and Smith 2010, Smith 2018). Friendship is analytical because it is a concept that opens a space to understand and think about politics, and it denotes a certain theoretical problem: how we can identify and understand the bonds between person and person, group and group. It is descriptive because when the concept is properly calibrated or demarcated it is possible to both see friendship working in politics, and to study instances of its working. Finally, it is normative because friendship can be understood to not only indicate relations which are present, but also to suggest how relations should be constructed. In this respect significant work in political theory has outlined just what friendship can contribute to the vitality of existing societies (Friedman 1993, King 2007), and what a civic friendship would look like (Schwarzenbach 1996, 2009). In this article, friendship helps us to understand the contemporary scene, and to contribute to a new and more ethical form of politics. 
It is important to stress at this point what is intended by 'friendship'. For although a growing body of work has emerged which locates friendship in politics, there have also been objections to the suggestion that friendship might form the basis for a normative political ideal or model (Keller 2009, Wellman 2001, Healy 2011). These objections are understandable insofar as what many consider the gains of modern European politics have been realised precisely because Europeans have effected a shift from a focus on small-scale community to that of a more enlarged society. In other words, modern European political thought tends to stress the public, general, and rational. Friendship appears to be associated with a former world outside of modernity (Devere and King 2000). Friendship is assumed to be a relationship that is characterised by the private, particular, and affective. And so it is - but this is not all that it is. To claim so is to mistake a member of a set for the entire set. Two things can be said about this. First, cultural and historical work has shown that this view of friendship is far from the universal view. Indeed, such work has shown huge cultural and historical variation in the understanding, use, and practice of friendship. Second (and partly as a consequence of this wider appreciation of the variation of friendship), there are significant difficulties in defining friendship. Defined too widely friendship includes too much: everything becomes friendship (and so nothing is really friendship). Defined too narrowly friendship is specified out of existence: nothing can be considered an instance of friendship (Smith 2011). This problem has led to an influential approach to the study of friendship that draws on the work of the later Wittgenstein and has been developed by theorists such as Digeser (2013, 2016). Here friendship is understood to be a 'family resemblance' concept. In this understanding friendship has multiple instances. Whilst there is no core definition or archetype, each instance of friendship has overlapping features with some other instances. Thus, instances of friendship share some features with others, but not all features. Friendship admits variety.

Thus, when we speak of friendship we draw on a concept that includes personal relations, but is not to be reduced to them. What is being discussed here is a field of concern about relationality and the possibilities of what binds person to person - and what separates them. Friendship does not simply indicate varieties of friendship, but a certain way of thinking about relations and the political. Friendship starts from the premise that politics is built upon the co-constitution of self and other, who inhabit a shared world, and whose relations are dynamic. It is this tying and retying of the bonds or knots between persons which creates the political fabric onto which seemingly more stable entities are secured. Friendship, then, is a way of approaching political relations; and these relations are constitutive of political things. One such political thing is the idea and practice of community which has formed the work of politics in modernity and has found its most recent manifestation in 'populism'. It is to this that we now turn.

\section{The old politics of the new populism}

In the past decade there has been increasing interest in the rise of populist movements in the West. Whilst populist movements are sometimes thought of as a new form of politics, their impact and form perhaps disguise their longer pedigree (Judis 2016). The impact of these movements is clear. Virtually every European polity has its own form of populist party, figure, or movement, and in some states populists have not only shifted the agenda of so-called traditional political parties, they have also had direct electoral impact (Economist 2018). Despite this there is some difficulty in defining what - exactly - populism is. One of the obvious problems in defining populism is that it does not sit easily within traditional ideological positions. Indeed, some movements seem to have only the flimsiest connection to ideology as it is traditionally understood. This is evident across a number of European polities. Sometimes populism has been associated with the right (as instanced in France, Netherlands, Germany), but not exclusively so. There have been several movements which can be described as broadly leftist in outlook such as Five Star Movement in Italy and Syriza in Greece. Perhaps most prominently, this 'Western' 
phenomenon has been replicated in its greatest hegemon: the USA. Although many see the rise of President Donald Trump as both shocking and surprising, it is perhaps best not seen in isolation from developments across the 'West' as whole. The rise of 'Trump has its own local conditions of possibility, but it can be understood to be a part of a wider trend.

A body of scholarship has tried to explain the rise of populism. Noting the difficulties in definition, this scholarship is also attentive to marginalisation of traditional ideology in populism. Although there are differences in their accounts of populism, scholars such as John B. Judis, Cas Mudde, and Jan-Jerner Müller understand the core of populism as centred around the trope of a corrupt elite against a pure people. Thus, Judis (2016) claims that populism is neither about the left-right divide, nor an ideology, but a kind of political logic. Nevertheless, he makes a distinction between populism's left and right wing variants arguing that whilst the left-wing variant assumes a purely vertical relation (the elite vs. the people), the right-wing variant is triadic as it also involves an outgroup. Müller (2017) argues that one of the distinctive features of populists is their claim that they alone represent the people. Exclusive varieties (which tend to be seen in Europe) appeal to 'the people' by shutting out stigmatised groups. Mudde and Kaltwasser have extended this argument by suggesting that populism can be further characterised as either 'inclusive' movements that tend to be open to stigmatised groups (such as those in Latin America), or as 'exclusive' movements (such as those in Europe) which focus on 'an ethnicized people, excluding “alien” people and values' (Mudde and Kaltwasser 2012). Finally, Mudde (2004) explains the leftright variance by arguing that at the centre of populist claims is the idea of the pure people versus the corrupt elite, and that this very thin ideology can be attached to thicker ideologies.

Whilst these studies go a long way towards understanding populism, here we approach the phenomenon from a different angle. In this article we see the rise of populism not simply as a contemporary phenomenon with longer historical roots, but a symptom of something much more fundamental in Western political thought. We suggest that populism is the latest symptom of a pattern of thinking that has been implicit in Western political thought since the outset of modernity - a pattern that has been exported globally through the related notions of 'the people', 'nationhood', and 'sovereignty'. This pattern of thought is focused on the desire for a unified political community. This yearning for community is seen in the basic dynamics of these movements (cf. Taggart 2004). As has been noted, populism tends to pit a homogeneous 'people' against a corrupt (and corrupting) elite. The desire of populism is to release the people from their repressive political bonds, thus making the people free and capable of realising their potential. Furthermore, there are significant affective elements to these movements. In other words, what binds or connects the members of these groups is feeling. The members of the group feel connected, and their togetherness is threatened or undermined by others. Commenting on the role of such affect, Žižek (1993) has argued that the imperative of the nation is to enjoy itself the other or stranger steals that enjoyment. The other prevents the nation from being whole. This results in hostility to the other, both in domestic and international politics.

In order to start to think about these claims it is worth dwelling on the success of Donald Trump. As Mudde has argued, Trump did not start out as a populist, but became one (quoted in Friedman 2017). Trump's slogans of 'drain the swamp' and 'crooked Hillary' fit perfectly with the characterisation of populists presenting themselves as representing the people against a corrupt elite. The irony of the billionaire Trump fighting the elite and being a 'man of the people' is not lost on commentators - but nor is it unusual. Diverging from the view that the people simply hate elites, Mudde has commented that what the people oppose 'is being represented by an "alien" elite, whose policies do not reflect their own wishes and concerns' (Mudde 2004, 560). In any case, Trump's appeal goes beyond an attack on the corrupt elite. This can be seen by considering another of Trump's slogans: 'Make America Great Again'. This is a formula that compresses several assumptions. First, it looks back to a time when America was (believed) to be great. It is nostalgic, a trait common to many populist movements (for a discussion see Kenny 2017). 
Second, it projects the possibility of American greatness into the future. In other words, it promises. Third, what is America? Moreover, who is America? Trump's campaign rhetoric makes this abundantly clear - the white working class left behind by external liberal trade, and undermined and fragmented by successive waves of immigration. What Trump is appealing to is not only a particular demographic (white, working-class men and their families and their compatriots), but also to a community, or perceived community. 'America' is of course not everyone, not even all Americans. The real or authentic America is threatened, undermined and cheated by internal and external others such foreign nations who are exploiting the USA economically (especially China which Trump accuses of committing trade 'rape' against the USA (BBC 2016a)), and immigrants who bring violence, lawlessness, and social breakdown (especially from Mexico which is said to be laughing at the USA (BBC 2016b)). Yet those who subscribe to Trump's America are clearly diverse and statistically more heterogeneous than his rhetoric would imply (BBC 2016). The demographic that Trump appeals to are made to feel as if they were connected and had more in common than their diversity would otherwise suggest (Gusterson 2017, for a more general discussion see Spruyt, Keppens and Droogenbroeck 2016). 'America' signifies 'community' and, as we will see, community implies inclusion and exclusion.

This logic underpins a number of similar movements. Most notably, the British vote for Brexit can also be seen in this way. Although some voters were motivated by nakedly racist considerations, right and left offered arguments that could be understood in terms of both a lost community, and the possibility of a community restored. Here a 'sovereign UK' became the signifier of community. For the right, the community was represented by a sovereignty that is undermined by the 'other' of the EU (Economist 2016). In the imaginary of the right, this sovereignty represented a long tradition of the UK as an island nation based on tradition and trade. Removing the European influence and controlling borders 'once again' would restore this lost community and togetherness. Left-wing arguments ran parallel to these (see for example, Guinam and Hanna 2017). Here the idea is that coherent and supportive communities once existed in the UK. The EU is portrayed as an economically liberal project that has destroyed these communities by undermining workers' rights, especially with its focus on liberal trade. Most crucially, the rights and conditions of UK workers (which are read to include access to welfare) have been undermined and fragmented by successive waves of 'cheap' foreign labour from the $\mathrm{EU}$, and demands by 'outsiders' on the legitimate claims to welfare of the British. In both the left and right-wing arguments for Brexit the idea of community becomes important. The British are taken to be a homogeneous group, a group which can be bounded and sovereign, and this is threatened by the existence of an exploitative outgroup.

Thus, although there has been a challenge to the politics of left, right, and traditional parties, it is far from clear that there has been a deeper shift in the aims of politics. The populist movements repeat the modern trope of community. A longer view would link current populist movements to the eruptions of revolutions and nation-building that have been such a central part of European modernity. In the next section we develop a fuller account of the meaning, significance, and limitations of community, before going on to explain what friendship might add to this picture, and how it might form an alternative plane of analysis.

\section{Community and its limits}

In his seminal work Gemeinschaft und Gesellschaft Ferdinand Tönnies distinguishes two kinds of human association (Tönnies 2001). The first of these is gemeinschaft (community). Tönnies characterises this as being a personal form of social interaction based on feelings of togetherness (Tönnies 2001, 22). Members of such a community view the community as an end in itself. Tönnies describes community as understood to be both natural and organic (Tönnies 2001, 31). In contrast, gesellschaft (society) is characterised by impersonal and formal relations. Members of 
the group have individual and self-interested aims that extend beyond the group (Tönnies 2001, 52). The group itself is sustained only insofar as it is instrumental to enabling the members' individual goals. Such a society is described as artificial and mechanistic (Tönnies 2001, 19). Tönnies understood this distinction to be a conceptual tool and argued that actual forms of human association were mixed. Nevertheless, gemeinschaft is predominantly associated with premodern societies, whereas gesellschaft is associated with modern market and industrial societies.

Much work has been undertaken on the alienating and atomising consequences of gesellschaft (and perhaps not unexpectedly, one proposed response to this is a return to gemeinschaft). Given the focus of this article, it can also be noted that although gesellschaft would appear to be a hostile environment for friendship, this conclusion might be premature. Indeed, the early theorists of commercial society such as Smith, Hume, and Ferguson, all saw a role for friendship as a freely chosen relationship built on reciprocal need which would be strengthed as traditional forms of association dissolved (Hill and McCarthy 1999). More recently, theorists have also attempted to show what role friendship can continue to play in societies of the late $20^{\text {th }}$ and early $21^{\text {st }}$ centuries (Scorza 2004, Edyvane 2007, May 2012). Yet although forms of association characteristic of gesellschaft have sometimes been understood to be the core of liberal modernity, gemeinschaft has continued both in substance and as an ideal. Indeed, a central claim of this article is that there is a strand of modern European thinking where gemeinschaft continues both as an ideal and as affect insofar as European modernity continues to focus on the possibilities of 'community'. This is at once something nostalgic, a lost time to be recouped or repaired, and something future-orientated, a work to be undertaken or a project to be completed (Bernasconi 1994, 3, Kellogg 2005, 339340). As Jean-Luc Nancy has claimed, 'Until this day history has been thought on the basis of a lost community - one to be regained or reconstituted' (Nancy 1991). What, then, is this community, and why do we claim that it must be supplemented with friendship? In what follows the problems and limitations of community will be discussed by grouping them around three broad themes: fantasy, identity, and community as the 'task' of politics.

The first set of problems revolve around the idea of community as fantasy. Here the point of departure is Benedict Anderson's study of nationalism (Anderson 2006). From our current perspective, the nation is an instance of community, and Anderson proposes that nationalism and the nation be understood as a form of 'imagined community'. Anderson notes that the nation is 'imagined as both inherently limited and sovereign' (Anderson 2006, 6). Anderson explains that the nation is imagined because the members cannot know each other 'yet in the minds of each lives the image of their communion' (Anderson 2006, 6), and it is a community because 'the nation is always conceived as a deep, horizontal comradeship' (Anderson 2006, 7). For Anderson it is this 'fraternity' that makes it possible for people to kill and die for the nation. In what follows Anderson's thinking is taken further. First, what can here be said about the nation can usefully be generalised about wider groups. Indeed, whilst it is recognised that Anderson's purpose is to give an historical account of the rise of the nation, Anderson's characterisation of the nation could apply to a number of groups including the notion which occupies us here - community. Second, although Anderson is interested in the affects of imagined community (especially where it motivates an individual's willingness to die for their nation) we wish to think of the community as simply being more than 'imagined', we propose that community is a 'fantasy'.

Why this change of nomenclature? This modification might appear small, but it signals something much larger. A fantasy implies something more than that which is simply imagined. Whilst the imagination can be dry and intellectual, a fantasy implies both an engagement of affect, and the desire for something beyond the currently experienced reality. Community is one such fantasy. As Bauman $(2001,1)$ has observed, community has a 'feel' to it; community is a 'warm... cosy and comfortable place'. It is a place where 'we can count on each other's good will' (Bauman $2001,2)$. Bauman goes on to argue that the history of the meaning of community connects it to 'an understanding shared by all its members' (Bauman 2001, 10 italics in original). This sense of 
community is affective because it connects what the members share, and what the members share is their feeling of connection to each other. However, just as fantasy suggests affects it also suggests something impossible - or at least beyond the realms of the real. In this sense community can be observed to always lay completed in the past, or to be completed in the future. No present community (however it is thought of) is considered complete or pure. All community, when it is dreamed, is experienced in the present as incomplete, fragmented, or under attack.

The second set of problems associated with community is generated by its focus on identity. For theorists such as Nancy $(1991,2003)$, community focuses on features of individuals which are understood to be essential to each of them, but which are held in common. As Nancy claims, this makes community a single thing. The relations between persons are lost to the image of a single overarching individual or signifier: the community. Such a vision undermines diversity. Ultimately what is sought is a totalising gemeinschaft (Strysick 1997, 202). In this vein, Bataille also asserts that traditional community sacrifices what is shared for what is merely held in common. In other words, community undermines the relations between persons, the relations that constitute persons, for features or attributes of persons that they happen to have in common. This form of signification, where one thing is assumed to stand for the whole of something else, is central to the idea of community. According to Nancy:

All-powerfulness and All-presence, this is what one always asks of the community or what one seeks in it: sovereignty and intimacy, presence to self without flaw and any outside. One wants the 'spirit' of a 'people' or the 'soul' of a gathering of 'faithful', one wants the 'identity' of a 'subject' or its 'propriety'. (Nancy 2003, 24)

The fantasy of community is thus based on an arbitrary and unsustainable sameness. It works on the basis that a signifier (a particular characteristic or property) can subsume all the single beings. According to Tuna $(2014,265)$, Nancy's objection here is that 'it leads us to regard signification as complete and absolute when in fact it is always partial'. Despite the desire for completeness, something always stands outside of community. In this way, community aims at an impossible immanence (Bernasconi 1994, 4). Put succinctly, community attempts to make an irreducible plurality into a unified singularity.

This focus on identity and immanence also leads to a logic of hostility to difference. In other words, it leads to a logic of us and them. This is a result of community's focus on what is common. Some commentators have been concerned with the negative effects of this. For example, Strysick has commented that 'community is traditionally defined by what is common among individuals; I am concerned with the negative way in which exclusion functions in community despite community's declared goals of inclusion' (Strysick 1997, 196-197). In this sense, not only does community in its modern forms such as the 'nation state' no longer afford 'a realistic perspective for achieving inclusive and overarching political identity' (Schwarzmantel 2007, 459), but the focus on identity is also the source of direct and murderous violence (the conflict in Kosovo between 1998 and 1999 being one of the most brutal examples at the close of the Twentieth century).

Finally, not only does community centre around identity, it is also understood to be a task, project or work that should be the overall focus of political action or a political programme. Community is a task because it demands its own realisation. This means that politics is understood to be structured by the idea that a better, fuller, or more complete community is both possible and desirable. As has been noted, this 'more complete' community operates on a logic of inclusion and exclusion, identity and difference, sameness and otherness. If politics is understood and practiced in this way, then difference and otherness always become the impediment to the realisation of community. Furthermore, if politics is understood in terms of the task of realising community, it is also concerned with constructing the identity of its members (Korhonen 2006). Such constructions move away from dynamic relations between persons, and towards a focus on 
a narrow set of identified features or attributes of persons. Community as a task of politics slips into a totalising mission to achieve perfect immanence between its members and the impossible dream of a complete, harmonious, and homogenous whole.

\section{Towards a new politics: friendship}

The previous two sections focused on community as one of the central and structuring tropes of both populism and modern European political thought more generally. The discussion so far has suggested that there are some limitations to, and problems with, the idea of community. Any new politics would need to overcome these limitations and problems. In summary, community is focused on both a logic of identity and presence, and this has resulted in exclusion and violence. In this section a possible way of transcending the current political impasse created by the trope of community will be outlined: friendship. As was suggested in the introduction, it is not claimed in this section that friendship simply 'replace' community. What is suggested is that friendship provides an alternative mode of analysis which offers a supplement to the established tropes of Western political thought (cf. Farrands 2001 who has made a similair analysis of relationship between friendship and citizenship, and Onuf 2009 who has discussed the relationship between friendship and hospitality). In so doing the article points to an alternative way of conceptualising and practicing politics. If community must coalesce around identity, friendship coalesces around difference. If community is concerned with the beginnings and the endpoint of its own realisation, friendship cannot trace its origins and resists all endpoints or destinations. If community is a task of politics concerned with achieving an identifiable, complete and full togetherness, then friendship stresses the incompleteness of all relations and the need to understand politics as an ongoing, dynamic, and non-teleological way of being with others.

As has previously been suggested in the initial thumbnail sketch of friendship, treated analytically, friendship denotes a particular field of concern. That field of concern is what binds person to person, group to group. To be concerned with friendship is to be concerned with the fabric out of which politics is constructed. In this respect we argue that friendship can be conceptualised as having five important features: (1) that it is a relationship; (2) between self and other; (3) which exists between the friends; (4) which is extendable into a network but not a unity; and (5) which eschews all programmes or projects. These five properties not only show the contrast between friendship and community, but also indicate the space that friendship fills. They show how friendship can be used as both an analytical and normative concept. The concept can be treated analytically because it helps to elucidate the structure of politics. The concept has normative import because it suggests an ethos with which to approach relations. This is especially important in the space of the new politics where old certainties are brought into question, and new political movements and assemblages are rapidly constructed and transformed.

The first thing to note about friendship is, then, that it is a relationship. This means that it is not a role, or an achieved state, but a dynamic. As a dynamic it displays both continuity and change. Indeed, the notion of friendship implies the development of shifting stabilities over time. In other words, and in contrast to community, friendship is not built around the identification and realisation of core attributes held common to its members. Whilst friendship might involve attributes which its members share, the structure of the friendship changes over time. Indeed, in this sense change is intrinsic to friendship.

This ties in closely with the second feature of friendship, that friendship is a relationship between persons. We saw that one of the limitations of community was that its attempt to achieve immanence was predicated on persons holding particular attributes or features in common. This led to a form of identity politics which was built on same-same or self-self relationships. Under such a scheme, difference and the other were excluded. In contrast, friendship involves a relationship between self and other. However, this claim involves something more than simply 
saying that a homogenous self is related to a heterogeneous other. To see what this might imply, consider Aristotle's paradigmatic way of understanding the relationship between friends. In Aristotle's account the friend is another self (Aristotle 1985, 246). What Aristotle means by this is that although the friends are separate from each other (they do not share a self), nevertheless the friends treat the other as their own. In Aristotle's account this is possible because (in character friendship at least) just as the virtuous man loves the good in himself so he loves it when he recognises it in others. As such, Aristotle's friendship is a friendship of same-same, or self-self. This is the kind of friendship which is replicated in community - although in the modern era it is often shorn of Aristotle's concern with virtue and the good, and focused instead on features which are held in common (such as nationality, religion, or ethnicity). In contrast, by claiming that friendship is a relationship between self and other, two vectors are invoked. First, the friends connect not just in terms of their similarities, but also their differences. What brings the friends together is a mixture of identity and difference, self and other. Second, that friendship is a selfother relationship also points to the idea that the friends themselves are composed of both sameness and difference, self and other. In other words, the person is not immanent to their own self, but a complex. Thus, saying that friendship is a self-other relationship indicates that friendship is a complex intermeshing of persons, and that no person is complete or sufficient in their own right. Understood politically this means that the 'political subject' (community) can never be realised. The heterogeneous elements can never be expelled or extinguished, but friendship suggests that there is no need to do so. Heterogeneity and homogeneity, sameness and difference, can be held in relation.

This brings us to the third feature of friendship; that as a relationship between self and other it exists in neither of the friends. In other words, friendship is not something that either of the friends possess, it is something that can only exist between them and is shared. Indeed, here we would like to go further and suggest that what the friends share is a sense of self. In caring for the friendship the friends care not for their own self, nor for the self of the other, but some shared self that exists between them. In a sense this feature of friendship echoes some of the ideals of community. This connection is perhaps not merely coincidental. Indeed, Aristotle has remarked that friendship is the basis of community(Aristotle 1985, 208). However, whilst friendship and community are related in this respect, friendship is differentiated from community in respect to the role that difference plays in the sharing of a self in friendship.

The importance of difference becomes even more apparent when we consider the fourth feature of friendship; that it is an extendable relation. Although all friendship is at least dyadic insofar as friendship can exist between two persons, it is not limited to the dyad. In fact, the connections between sameness and difference which characterise friendship can be infinitely reconfigured and rearranged. Moreover, one friendship does not foreclose the possibilities of other friendships. Friendship need not clash with friendship. Unlike community, friendship is not a system of identity and difference, but a system of difference and identity. It is the difference between the friends, their spaces and their contrasts, which constitutes the friendship and holds the friends together. There are no core similarities between the friends, indeed the changing nature of friendship points to those similarities changing over time in any case. Friendship does not stand still. What we see, then, is not a series of closed or concentric circles, but a whole criss-crossing of connections between person and person, group and group. This criss-crossing binds together sameness and difference, self and other, and is endlessly capable of reconfiguration.

Fifth, in contrast to community, friendship offers no political task, programme or project. Its strength is not what it seeks to realise, but that it simultaneously holds persons together who share a world, without direction or terminus to their relationship. It does not aim to realise a specific way of being with others, it is instead an on-going way of existing. Friendship is capable of multiple variations without exclusion. Given that it offers no programme and that it resists all attempts to define it, friendship is anarchic and anti-authoritarian. In this sense, friendship is post- 
foundational (for a discussion of post-foundationalism see Marchart 2007). In contrast to community, these features make friendship uniquely placed to analyse the new politics and to contribute to a new ethos. Friendship can do so because it escapes the traps of community which tie this trope to a teleological form of politics which result in exclusions and hostility to others. Friendship moves beyond such exclusions because it eschews all attempts to reach a final resolution or conclusion. Whilst friendship speaks to the desire for togetherness insofar as it is a way of thinking about and practicing the bonds between person and person, group and group, it manifests as an ethos of sameness and difference, rather than a programme to realise self and the same.

Here, then, we begin to see how friendship is contrasted to community. We also begin to see the connection between friendship and politics. In this respect we can understand state and nation as instances of community but also as forms of friendship (Smith 2014). Friendship is understood to be a series of connective tissues. Politics is understood to denote a shared world of order and value. However, politics cannot be understood separately from its relations. These relations always exist, and the most basic of these is to be understood as friendship. Friendship is the most basic way of being-with-others, a way that is open-ended, unstructured, and replete with possibilities. What politics does is to identify and transform some of these relations privileging them over other possible relations, and ossifying them in political thought and practice. Thus in contrast to friendship understood at the ontological level as being-with-others, politics gives friendship definitive forms and specified purposes. Aristotle's friendships for utility are examples of this. These friendships (like political friendships) have specific aims and purposes. However, these friendships are not friendships understood at the ontological level; they are a specific form of friendship. In modern times, the state and the nation are two potent examples of this process (Smith 2014, 43-46). Thus the state and the nation should not be taken as political 'givens', but as special friendship groups. This is not simply to say that the state and the nation have a history, that, as a matter of fact, they have not always existed and have 'come into being'. It is to make a deeper claim that the state and the nation are one possible form that friendship can take.

Thus, the state and the nation are specialised friendship groups, but they are not the only friendship groups. This is where thinking about friendship has something to offer the analysis of modern politics and the new political space. In this analysis the state and the nation take up, develop, and transform existing forms of friendship. In other words, they do not create friendship ex nibilo - they take up and transform existing material. This existing material is the relations between person and person, relations which bring together sameness and difference, self and other. In taking up some of this material, politics achieves its ends of bringing together a space of order and value. However, two things should be observed. First, in doing so, the friendships that become codified could have been codified in other ways. Whilst friendship must operate in the political space there is more than one way to do this. As a result, any codification is contingent. It could have been some other way. Second, in creating political friendships the political leaves a remainder behind. In other words, in bringing forth some connections others are left undeveloped. There is a residue of friendship that is not taken directly into politics. This residue is not only what is excluded, it also points to the incompleteness of any political form. This is a crucial observation as it means two things. First, it means that there is always potential for political change. There are always new ways of doing things, new ways of relating in the shared space. The second is that this remaindered friendship adds to the instability of the political settlement. In other words, insofar as the remaindered friendship is marginalised or 'doesn't fit in' it offers the possibility of resistance and change.

Understood in this way, friendship points to a politics beyond community. Friendship does not seek to realise a whole, but an interconnecting and dynamic relay of sameness and difference. Friendship points to localism and the immediate, but this localism and immediacy is not a parochialism or a nearness in the sense of a geography of concentric (and ever decreasing) circles. 
On the contrary, the immediate other of friendship might be connected across time and space. To understand friendship in this way is to refashion our understanding of politics itself. It is to disrupt and displace the centre of community (be it in its left-wing or right-wing guises, be it a longing for the past or a hope for the future). If friendship is taken as the basic open-ended relation of self and other then community can never be completed. To think that community can be completed is to be subject to an intoxicating and dangerous fantasy. To understand politics as friendship is to understand politics as a connective dynamic of flows and resistances. Knots may appear where friends bond with friends. These act as both anchors and as resistance. Yet this is not the purpose of friendship. By focusing on relations the fabric is woven, but in an unguided way. Friendship does not offer a new community, but nor does it offer a new individualism. Friendship offers a way of returning to thinking about the relation between person and person, and the possibilities this holds for a network of sameness and difference, self and other.

\section{Conclusion: friendship and the new politics}

This article began by asking 'What role can friendship play in contemporary politics'? The answer to this question lies in understanding that friendship is a way of refocusing politics on relations. Friendship suggests that we need to look beyond fixed entities based on identity and sameness such as those offered by community to carry our politics. Friendship suggests that such entities are doomed to failure. First, they can never be completed because they fail to attend to the dynamic and transformative aspects of human relations. Second, they work on a logic of inclusion and exclusion which is mapped onto a hostility to difference and otherness. Friendship points to a way beyond this paradigm offering a vision of politics based on a mobile network of relations. Such a mobile network links identity and difference, sameness and otherness, and it is open to multiple points of connection. However, friendship is also differentiated from community insofar as friendship is not a task or project to be accomplished but an ethos with which to approach political relations. As such it opens and maintains a shared and diverse space for the development of political relations, and the creation of institutions, programmes, and policies.

The great convulsion of our times is that of populism. This has gripped the Western world and it shows no signs of abating. Indeed, current trends suggest the populists have a long way to go before they reach their peak. However, as we have suggested, the presence of populism does not point to something new. On the contrary, it points to the persistence of a perennial trope in modern Western political thought: community. No doubt community is reinvented in the populist discourse - it becomes 'the people', 'the nation', or 'the dispossessed' - but in all cases the logic is the same. What the supporters of populism long for is a time when the goodness and harmony of their community can be made complete. This does not simply involve a fight against elites, but also an identity politics of inclusion and exclusion, us and them, self and other.

In this way those seeking a progressive politics can be seen to be pinned on the horns of a dilemma. Since the end of the Second World War various forms of identity politics have arisen in the West, and feminist, gay rights, and anti-racism movements all stand as examples. Yet, there is something deeply paradoxical here. In fighting against the marginalisation of identity these movements reinforce identity. In so doing, they often reinforce difference and division. In this respect the Western Left has faced an increasing fragmentation since the end of the Second World War. As identity multiplies the ability to found collective action disintegrates. Moreover, the progressive Left is faced not only with multiple identities, but competing claims between these groups many of whom not only exclude others from their vision of community, but who see those others are impediments to that realisation. In this way, the Left remains captured by the trope of community, and the logic of identity, inclusion and exclusion that community entails.

This is not to decry the advances that have been made by those who have advocated a progressive identity politics. Clearly it is right to highlight the position of the oppressed, and to advocate for 
greater inclusion and justice. In this sense a strategic essentialism has made great political gains. However, the open-ended nature of friendship contributes to this picture a way beyond this strategic essentialism. Friendship's emphasis on difference and relations points to progressive and perhaps even surprising alliances and greater intersectionality. In fact, friendship suggests that it is the encounter with difference (rather than the encounter with sameness) that is the 'event' around which the most basic political relation can be built. A political relation which excludes difference is likely to result in an isolated politics of marooned communities. The Left is increasingly characterised by this condition. Its attempts to escape either through 'left-wing' populism (such as that of Bernie Saunders) or an appeal to communities of identity have led it back to the trope of community, and back towards the dangerous shores of conservatism and reaction. In contrast, could it be that friendship might provide resource for something more enabling? Could not friendship suggest a way for those who are oppressed and marginalised to connect without needing to reinforce their own positions with identity and community? Friendship suggests something beyond the established forms of politics, a kind of politics which does not rely on seeking the institution of a stable identity and wholeness, but instead suggests that all identity and relations must be continuously renegotiated, reassessed, and reaffirmed.

The new politics is thus a politics of mobility and fluidity. It will need to focus on relations and move away from identity. Crucially, the progressive Left cannot overcome the Right by relying on the trope that has held the two in a deadly embrace for so long: community. Populism - both of the Right and Left - is the latest and most troubling symptom of this fantasy. Friendship offers a new ethos which is suited to our times where both the global and the local are connected and where people form attachments and loyalties at multiple levels and with a diversity of others. Friendship is the open-ended and ongoing encounter of self with other, and its politics holds open a shared space for that encounter.

Acknowledgements: This article was funded by the Chiang Ching-kuo Foundation for International Scholarly Exchange (CS001-U-17). This article was first presented at the workshop 'Friendship and Politics: Cross-Cultural Perspectives' staged in Leeds in June 2018 where we were grateful for engaged comments. We are also grateful to an anonymous reviewer for their comments, and to Adam Roberts of The Economist for his thoughtful response.

\section{References}

Anderson, Benedict. 2006. Imagined communities: reflections on the origin and spread of nationalism. Rev. ed. London: Verso.

Aristotle. 1985. Nicomachean Ethics. Cambridge: Hackett Publishing Company.

Bauman, Zygmunt. 2001. Community: seeking safety in an insecure world. Cambridge: Polity Press.

BBC. 2016a. "China accused of trade 'rape' by Donald Trump", accessed 16 July 2018. https://www.bbc.com/news/av/world-us-canada-36185275/china-accused-of-trade-rapeby-donald-trump

BBC. 2016b. "Daca Dreamers: Trump vents anger on immigrant programme", accessed 16 July 2018. https://www.bbc.co.uk/news/world-us-canada-43612465

BBC. 2016c. "Reality check: who voted for Donald Trump?", accessed 22 April 2018. https://www.bbc.co.uk/news/election-us-2016-37922587 
Bernasconi, Robert. 1994. "On deconstructing nostalgia for community within the West: the debate between Nancy and Blanchot." Research in Phenomenology 23 (1993):3.

Devere, Heather. 2013. "Amity update: the academic debate on friendship and politics." AMITY: The Journal of Friendship Studies 1 (1):5-33.

Devere, Heather, and Preston King. 2000. The Challenge to Friendship in Modernity. London: Routledge Ltd.

Devere, Heather, and Graham M. Smith. 2010. "Friendship and Politics." Political Studies Review 8 (3):341-356. doi: 10.1111/j.1478-9302.2010.00214.x.

Digeser, P.E. 2013. "Friendship as a family of practices." AMITY: The Journal of Friendship Studies $1(1): 34-52$.

Digeser, Peter. 2016. Friendship reconsidered: what it means and how it matters to politics. New York: Columbia University Press.

Economist, The. 2016. "Dreaming of sovereignty" The Economist accessed 22 April 2018. https://www.economist.com/britain/2016/03/19/dreaming-of-sovereignty

Economist, The. 2018. "Dancing with danger: Europe's populists are waltzing into the mainstream." The Economist.

Edyvane, Derek. 2007. Community and conflict: the sources of liberal solidarity. Basingstoke: Palgrave Macmillan.

Farrands, Chris. 2001. "Touching Friendship Beyond Friendship: Friendship and Citizenship in Global Politics." Alternatives: Global, Local, Political 26 (2):143-173. doi: 10.1177/030437540102600203.

Friedman, Marilyn. 1993. What are friends for? : feminist perspectives on personal relationships and moral theory. United States.

Friedman, Uri. 2017. "What is a populist? And is Donald Trump one?" The Atlantic.

Guinam, Joe and Thomas M Hanna. 2017. "Lexit: the EU is a neoliberal project, so let's do something different when we leave it" NewStatesman accessed 22 April 2018. https://www.newstatesman.com/politics/brexit/2017/07/lexit-eu-neoliberal-project-solets-do-something-different-when-we-leave-it

Gusterson, Hugh. 2017. "From Brexit to Trump: Anthropology and the rise of nationalist populism." American Ethnologist 44 (2):209-214. doi: 10.1111/amet.12469.

Healy, Mary. 2011. "Civic Friendship." Studies in Philosopby and Education 30 (3):229-240. doi: $10.1007 / \mathrm{s} 11217-011-9221-3$.

Hill, Lisa, and Peter McCarthy. 1999. "Hume, Smith and Ferguson: Friendship in commercial society." Critical Review of International Social and Political Philosophy 2 (4):33-49. doi: 10.1080/13698239908403290.

Judis, John B. 2016. The populist explosion: how the great recession transformed American and European politics. New York, NY: Columbia Global Reports.

Keller, Simon. 2009. "Against Friendship between Countries." Journal of International Political Theory 5 (1):59-74. doi: 10.3366/E1755088209000329.

Kellogg, Catherine. 2005. "Love and Communism: Jean-Luc Nancy's Shattered Community." Law and Critique 16 (3):339-355. doi: 10.1007/s10978-005-1514-7. 
Kenny, Michael. 2017. "Back to the populist future?: understanding nostalgia in contemporary ideological discourse." Journal of Political Ideologies 22 (3):256. doi: 10.1080/13569317.2017.1346773.

King, P.T. 2007. "Friendship in Politics." In Friendship in Politics, edited by Preston.T. King and Graham M. Smith, 9-30. Oxford: Routledge.

Korhonen, Kuisma. 2006. "Textual Communities: Nancy, Blanchot, Derrida." Culture Machine: Generating Research in Culture and Theory 8.

Marchart, Oliver. 2007. Post-foundational political thought: political difference in Nancy, Lefort, Badiou and Laclau. Edinburgh: Edinburgh University Press.

May, Todd. 2012. Friendship in an Age of Economics: Resisting the Forces of Neoliberalism. US: Lexington Books.

Mudde, Cas. 2004. "The populist Zeitgeist." Government and Opposition 39 (4):541.

Mudde, Cas, and Cristobal Rovira Kaltwasser. 2012. "Exclusionary vs. inclusionary populism: Comparing contemporary europe and latin america." Government and opposition 48 (2):147-174.

Müller, Jan-Werner. 2017. What is populism? London: Penguin Books.

Nancy, Jean-Luc. 2003. "The confronted community a." Postcolonial Studies 6 (1):23-36. doi: $10.1080 / 13688790308110$.

Nancy, Jean-Luc. 1991. The Inoperative Community: University of Minnesota Press: USA.

Onuf, Nicholas. 2009. "Friendship and Hospitality: Some Conceptual Preliminaries." Journal of International Political Theory 5 (1):1-21. doi: 10.3366/E1755088209000299.

Schwarzenbach, Sibyl A. 1996. "On Civic Friendship." Ethics 107 (1):97-128. doi: $10.1086 / 233698$.

Schwarzenbach, Sibyl A. 2009. On civic friendship: including women in the state. New York: Columbia University Press.

Schwarzmantel, John. 2007. "Community as Communication: Jean-Luc Nancy and 'Being-inCommon’." Political Studies 55 (2):459-476. doi: 10.1111/j.1467-9248.2007.00625.x.

Scorza, Jason A. 2004. "Liberal Citizenship and Civic Friendship." Political Theory 32 (1):85-108. doi: $10.1177 / 0090591703252378$.

Smith, Graham M. 2011. Friendship and the political : Kierkegaard, Nietasche, Schmitt. Exeter: Imprint Academic.

Smith, Graham M. 2014. "Friendship, state, and nation." In Friendship and international relations, edited by Oelsner, Andrea and Simon Koschut, 35-50. Basingstoke: Palgrave Macmillan.

Smith, Graham M. 2018. "Friendship as a political concept: a groundwork for analysis." Political Studies Review.

Spruyt, Bram, Gil Keppens, and Filip Van Droogenbroeck. 2016. "Who Supports Populism and What Attracts People to It?" Political Research Quarterly 69 (2):335-346. doi: 10.1177/1065912916639138.

Strysick, Michael. 1997. "The End of Community and the Politics of Grammar." Cultural Critique (36):195-215. doi: 10.2307/1354504.

Taggart, Paul. 2004. "Populism and Representative Politics in Contemporary Europe." Journal of Political Ideologies, 9 (3):269-288. doi: 10.1080/1356931042000263528 
Tuna, Emine Hande. 2014. "The underridization of Nancy: tracing the transformations in Nancy's idea of community." Journal for Cultural Research 18 (3):263. doi: 10.1080/14797585.2013.874630.

Tönnies, Ferdinand. 2001. Community and civil society. Cambridge: Cambridge University Press.

Wellman, Christopher Heath. 2001. "Friends, Compatriots, and Special Political Obligations." Political Theory 29 (2):217-236. doi: 10.1177/0090591701029002003.

Žižek, Slavoj. 1993. Tarrying with the negative: Kant, Hegel, and the critique of ideology. Durham, NC: Duke University Press. 